\title{
Self-determined motivation of young people to the sport leisure
}

\author{
Fairouz Azaiez ${ }^{1,2}$, Nasr Chalghaf ${ }^{2}$, Abdelhakim Cherif ${ }^{1,2}$,Karim Achour $^{2}$, \\ Mouna Ouaz ${ }^{1}$ \\ ${ }^{1}$ Higher institute of Sport and the Physical Education of Sfax (Tunisia) \\ ${ }^{2}$ Studies Group of Development and Social Environment (Faculty of Letters and Social Sciences of Sfax)
}

\begin{abstract}
Theaim of this study was to analyze the relationship between the motivations of young people from the region of Sfax (Tunisia) towards the sport in relying on the theory of self-determination (Deci, e. l., Ryan, R.M., 1985).

To achieve our goals, we had a questionnaire to 420 youth (221 male and 199 female) entitled 'the level of Motivation towards recreation' (EML-28) (Deci, E., E.R. Vallerand, L.G. Pelletier, and R.M. Ryan 1991).

The correlation also seems to be good, the results obtained have led us to design the persistence of an intrinsic motivation stimulation and the fulfillment that mobilizes our youth to sport (taste to try new moves, the satisfaction felt when doing movements and the pleasure of driving and sports challenges). Youth in the area of Sfax are more oriented toward an intrinsic motivation to stimulation. With regard to the relationship of youth based on the genre towards the sport, there is a non-significant difference between self-determined motivation and kind.
\end{abstract}

Key words: Motivation; Theory of self-determination; leisure; youth.

\section{Introduction}

Theamotivation is a key concept to explain commitment, maintenance or abandonment of health behaviour, including the activity of leisure of young people (Carey; Lewis, 1999; Ridder; Wit, 2006). It can be defined as the built hypothetical used to describe internal and/or external forces producing the trigger, direction, intensity and persistence of behavior (Vallerand\&Thill, 1993). A relatively large number of theoretical models to better understand and explain the motivational Dynamics exist in the literature (Biddle, Treasure, \&amp; Wang, 2008; Deci\&amp; Ryan, 2002, 2008).

The Self-determined theory (Deci\& Ryan, 1985, 2002; Schelling, Munsch, Meyer, Newark, Biedert, \&Margraf, 2009; Sarrazin, Pelletier, Deci\& Ryan, 2011) seemed to us to be an appropriate theoretical framework in order to address the problem of the youth engagement in the leisure activity.

The contribution of leisure to the collective well-being is increasingly recognized (Darling, Caldwell, \& Smith, 2005). The motivation is probably the most used psychological process environments (Standage, Duda, \&Ntoumanis, 2006) sports recreational activities. It is considered one of the factors key to persistence, also a difficult concept to understand because it manifests itself in ways very different and also because usually discussed his trip or its deterioration causes numerous, varied and sometimes contradictory (FrederickRecascino, 2004).

The area of the sport, as several areas, also has recourse to self-determined motivation (Miller, \& Brown, 2005). The time given to the sport is a place increasingly important in our lives. To find his mental and physical balance, human being needs to break free (Lu, Feng, 2008).

In addition, availability and proximity to facilities (land, halls,) make the sport more attractive and accessible to everyone. Each of the practitioners has its own reasons and his own motives that push him to engage in such activity (Ryan \&Deci, (2008). Various leisure sports practices are among the major strengths of the social and economic development of modern Tunisia.It is through these leisure activities that youth shape their personality and free of all constraints (Sabiston, \& Crocker, (2008).

The field of recreation was the subject of important theoretical developments in the twentieth century (Smigel, 1963; Szalai, 1972; Kelly,1982; tinsley ;Tinsley, 1986; Samdahl, 1988). The practice of recreational activities can have a positive impact on the physical health and mental health of individuals (Iso-Ahola, 1980; Kelly, 1982; Neulinger, 1974).

Several recent studies attempted to investigate this issue (Neulinger, 1974; Simono, 1991). The results of his studies make leisure and recreational activities allow the psychological well-being (intellectual stimulation, self-esteem, stability, personal efficiency, reduction of stress etc.) (Tinsley, 1984).

It is very important to distinguish between charged for extrinsic reasons recreation and leisure for intrinsic reasons. Indeed, all recreational activities are not qualified to positive (Hormuth, 1986; Neulinger, 1984). 
The concept of free choice of activity has an important role in the practice of recreation which is not only affiliated to the intrinsic reasons. Indeed, the activity freely choice is practised to intrinsic and extrinsic reasons (Mannell\& al. 1969; Tinsley \& Tinsley, 1986).

In the absence of a theoretical framework to integrate the various reasons that underlie the practice of recreation, (Deci\& Ryan, 1985, 2000, 2002) have recently recommended to use the theory of selfdetermination in order to distinguish the recreation practiced for pleasure and satisfaction (free choice) or the absence of pleasure.

A substantiated outside person (rewards, punishments, social constraints) is not particularly interested in the activity itself. The practice is assigned to produce pleasant results or to escape unpleasant consequences (Deci, 1975). Soa person is intrinsically motivated when she practices a leisure activity voluntarily and by interest. So here, the individual feels competent, effective and self-initiated (learn something new or explore new activities) (François L. Rousseau 2002).

The person is amotivative when he is unable to consider and identify the consequences of his behavior. Therefore this person living an experience of loss of control lies one of the features of Sports leisure in a hedonistic sighting, corresponding to a time and activity outside the constraints. It corresponds to an activity carried out for herself, for the pleasure. Like the game, the Sports leisure is usually autotelic (which in its own end in itself), but it can also be considered as a means. More often, he was a way of meeting, or the way to spare time for itself, out of professional and family frameworks. (Coulbaut, 2008).

The results of the study by Pelletier, Vallerand, \&Briere (2003) indicate that only the types of intrinsic and extrinsic motivation self-determined (identified regulation) are positively associated with measures of psychological well-being. Extrinsic motivation byintrojected regulation is also associated with welfare, but at a significantly lower level. Finally, extrinsic motivation by external control and the amotivation are negatively associated to psychological well-being.

Some studies have found that women have a more intrinsic profile and self-determined than men, while the latter are more external regulation and amotivation (Pelletier, Fortier, Vallerand, \&Briere., 2001).

The motivation produced negative consequences, such as the decrease in concentration, self-esteem, life satisfaction, performance and retention activities. On the other hand, the fact of participating in activities by intrinsic motivation leads to positive consequences, such as greater cognitive flexibility, a better conceptual learning, creativity, greater interest, positive emotions and a better self-esteem.

The level of self-determination seems to represent a significant dimension to understand the relationship between leisure and the psychological consequences of the practice. Only recreation or individuals who have a perception of free choice or a perception of pleasure in practicing their activities would be positively related to psychological well-being. (Pelletier, Vallerand, Briere, 2001).

According to a survey (Bouhelee,2005), the major reasons for practicing a sport leisure were especially to acquire know-how, to cultivate, acquire autonomy or get distracted. So the motivation is rather extrinsic either identified or well regulated inintrojected regulation. Two studies conducted with young adults attending a fitness room showed a rate of superior adhesion among practitioners having grounds to intrinsic practices (Ryan \&Deci., 2008). For a very large majority of Europeans (78\%) (Eurobarometer, 2004), the sport is before all a hobby and the key is to have fun, decompress and spend without counting. The most competitive are less than 18 years. Men are somewhat more likely than women to have the spirit of competition: $25 \%$, compared to $12 \%$. Among the main reasons that push the Europeans to do sport, $40 \%$ see that sport is above all a way to decompress, to forget the stress of studies or work. This is the main reason given by the age of 50 years. Therefore, this category is mobilized by an extrinsic motivation tointrojected regulation. For 50 years and more, it is the positive impact of sport on health which justifies the practice of sport. Therefore the motivation is well extrinsic to identification.

Although these studies (Ewing \&Seefelt, 1996; Gill, Gross \& Huddleston, 1993; Wankel\&Kreisel, 1985; White, Duda\& Keller, 1998) do not provide all of the same reasons, certain themes are recurrent. The first reason given by young people is fun and pleasure. When they do play, young athletes are other things to do, such as learn new techniques, work his physical condition, know the competition fever and make new friends (Roberts, 2001; Feltz, Irwin, \& Kerr, 2011).

\section{Method}

The population consists of 420 young people (221 male and 199 female) belonging to the region of Sfax (Tunisia), old averaged 25.5 years and with a standard deviation of 5.32. The instructions given to the young people reported that the objective of the study was to better design the reasons prompting young people to engage in leisure activities. It is in reported that participation in the study was voluntary, anonymous and confidential. 
The questionnaire used is the level of Motivation towards recreation (EML-28) (Vallerand, R. J., Pelletier, L. G., Blais, M. R., Briére, N. M., Senécal, C. B., \&Valliéres, E. F. (1992). to measure the reasons for the practice of the sport.

This scale is made up of 28 statements representative 12 under scales measuring three types of intrinsic motivation (intrinsic motivation intrinsic motivation to carry out knowledge, intrinsic motivation stimulation), three types of extrinsic motivation (motivation extrinsic-identified, motivation extrinsic-introjection and motivation extrinsic-regulation external) and finally, four sub scales measuring the amotivation.

\section{Results}

To verify the psychometric quality of the built, an orthogonal factorial analysis of type Varimax (kaiser, 1958) is performed on our questionnaire from the 28 items. In order to reduce the contents of the array, the weight of the items, by factor is registered by.40 criteria also by Acher and Haigh (1997).

These results indicate that the scale of assessment of motivation towards the sport(Vallerand\& al .1992) presents a good consistency internal (alpha $=.775)$ and good stability time $(r=$ test and re-test $=.789)$.

The results obtained from the correlation matrix between 07 motivation towards leisure items (table: 1), indicate that there is a positive correlation at $\mathrm{p}<.001$ between the majority of the variables such as practice a leisure activity for the pleasure of doing an activity serves the purpose to learn something new (intrinsic Motivation to knowledge) $(\mathrm{r}=.617 \mathrm{p}<.001)$, or for the choice to perform an activity and its motivation behavior arises from the person himself (Motivation extrinsic-identified) $(\mathrm{r}=.472 \mathrm{p}<.001)$ or for the pleasure and satisfaction (intrinsic Motivation to accomplishment) $(\mathrm{r}=.479 \mathrm{p}<.001)$. The action of the youth to the sport is conducted only by interest and pleasure that the individual action, without waiting for external reward.

Table: 1 - Matrices of correlation of motivation towards leisure

\begin{tabular}{|c|c|c|c|c|c|c|c|c|c|}
\hline & M & SD & 1 & 2 & 3 & 4 & 5 & 6 & 7 \\
\hline 1- Intrinsic motivation to knowledge & 2,99 & 934 & 1 &, $423^{* *}$ & $169^{* *}$ & ,617 ${ }^{* *}$ &, $393^{* *}$ &, $431^{* *}$ &,$- 187^{* *}$ \\
\hline 2- Intrinsic motivation to acomplishment & 3,12 & 918, & & 1 & $258^{* *}$ & $479^{* *}$ & $439^{* *}$ & $227^{* *}$ &,$- 258^{* *}$ \\
\hline 3- Intrinsic motivation to stimulation & 3,84 & ,711 & & & 1 & ,182** & ,177** & ,044 &,- 034 \\
\hline 4- Extrinsic motivation - identified & 3,30 & 920 & & & & 1 & $472^{* *}$ & $286^{* *}$ &,$- 387^{* *}$ \\
\hline 5- $\quad$ Extrinsic motivation - introjected & 3,32 & 862 & & & & & 1 & $404^{* *}$ &,$- 320^{* *}$ \\
\hline 6- Extrinsic motivation - external regulation & 2,45 & ,916 & & & & & & 1 &,- 067 \\
\hline 7- Amotivation & 1,68 & 831 & & & & & & & 1 \\
\hline
\end{tabular}

${ }^{* *}$. Correlation is significant at the 0.01 level (bilateral).

Sfax region youth have an amotivation inversely correlated with the intrinsic motivation (knowledge and fulfilling, respectively $\mathrm{r}=-.187 \mathrm{p}<.001$ and $\mathrm{r}=-.258$ to $\mathrm{p}<.001$ ) and extrinsic motivation (identified and introjected, respectively $r=-.387 \mathrm{p}<.001$ and $\mathrm{r}=-.320<.001)$ in to recreation. On the other hand, there is no relationship with the extrinsic motivation - external regulation and intrinsic motivation to stimulation.

The youth in the area of Sfax are more oriented towards an intrinsic motivation to stimulation ( $m e a n=3.84$ and $\mathrm{SD}=0.711$ ). When they do a leisure activity to feel the stimulating sensations that provide their practices or their interests. This is the sensory pleasure felt by the body when it comes in contact with water (swimming), air (run)... 
Table2: Reasons for practice leisures and gender

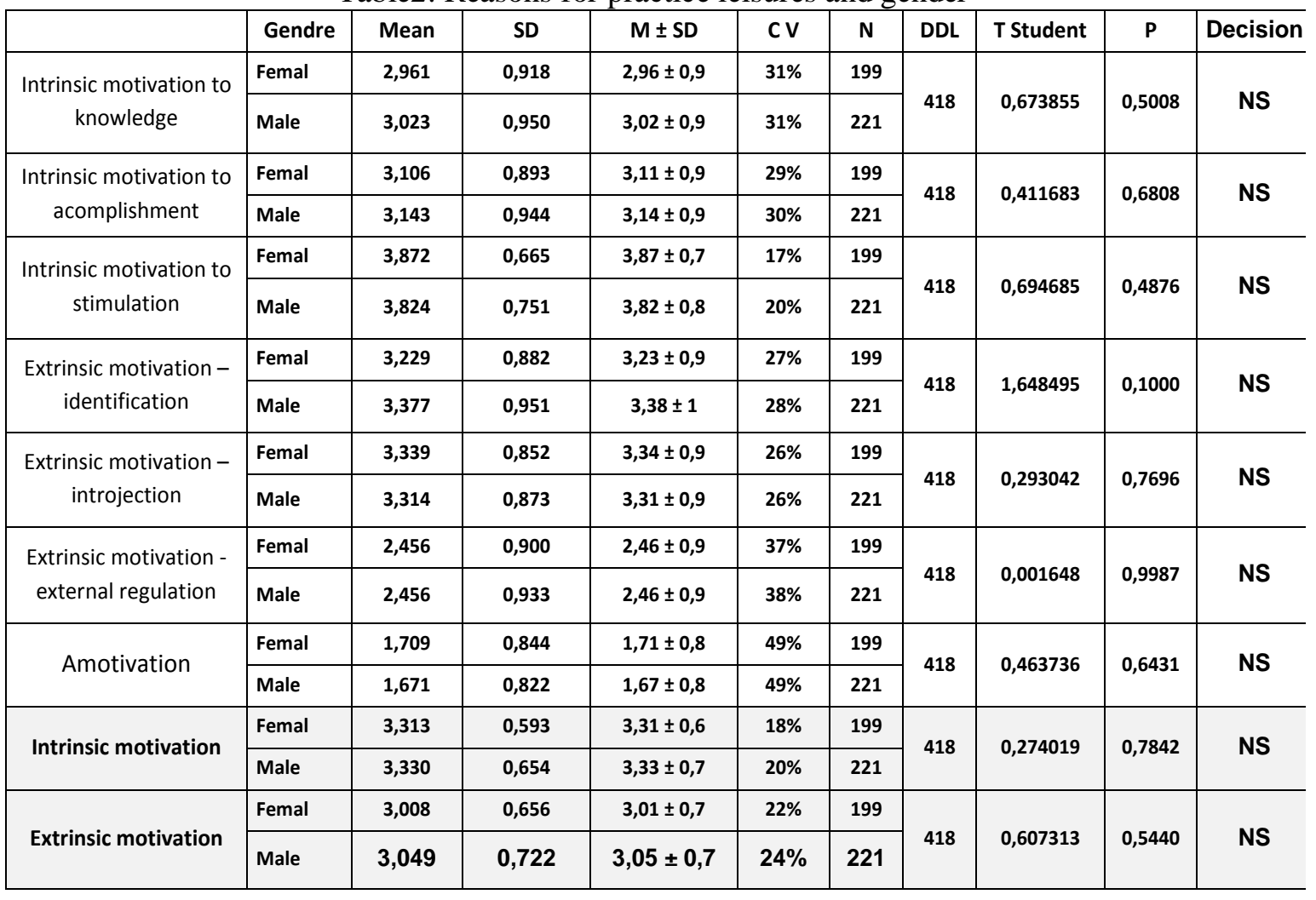

With regard to the relationship of youth based on the genre towards the sport, there is a non-significant difference between self-determined motivation and kind.

Intrinsic motivation, $\mathrm{t}(418)=0,2740 ; \mathrm{p}>.05$. Extrinsic motivation, $\mathrm{t}(418)=0.6073 ; \mathrm{p}>.05$ and finally the amotivation, $\mathrm{t}(418)=0,4637 ; \mathrm{p}>.05$ (table: 02 ).

\section{Discussion}

The current inventory (Motivation towards recreation) Vallerand, Pelletier, Demers, Blais, Briere (1996) designed for the evaluation of the types of motivations to recreation, built an important support for our research to clarify our problems and to test our hypotheses.

The results of the exploratory analysis show that the scale of motivation towards leisure of young people from the region of Sfax reproduces well the theoretical model with a satisfactory internal consistency ( $\alpha$ $=.775$ ) for all the 28 items of inventory (Kaiser 1958). These results are consistent with those of (Briere, 1995). Intrinsic motivation provides in the practitioner a huge fun (Ryan et al. 1997). The first motives teenagers pursuing physical activity after the onset of puberty are mainly based on the pleasure.

This same motivation also provides a pleasure to learn and discover new things (Deci, 1975), a performance and a better realization of itself (Chan Zason and Jhon Wang, 2008).

Correlation also seems to be good, the results obtained have led us to develop the persistence of an intrinsic motivation to stimulation and the fulfilment that mobilizes our youth to sport (taste to try new moves, the satisfaction felt when doing movements and the pleasure of driving and sports challenges). These results are consistent with those found by Kilpatrick, Hebert \& Bartholomew (2005); Sabiston, \& Crocker (2008). A diabetic declares Gourlan (2007), want to do three hours of weekly physical activity because he wants to be responsible for his health. Regular physical exercise is considered to be an essential element of the prevention and/or rehabilitation of various pathologies such as obesity (Avenell\& al,2004). Exercise has a beneficial role in Psychology (Atlantis \& al., 2004).

The stress of studies, the monotony of life and the unemployment grow our youth to have leisure practices, to relax, to be in good mood and feel care (Sarrazin, Pelletier, Deci\& Ryan, (2011)

Our young people practice a leisure activity to get satisfaction from an external cause to the practice of the activity itself. Is the individual sources of external contingencies but the source of control is inside him (Extrinsic Motivation - introjectee and identified). This source of control exerted pressure on the person (example: because he must make the sport to be in shape, because it is absolutely necessary to do sport to be in 
my skin, because I would feel bad if I did not take the time to and because it requires me to do sports regularly). These results are consistent with those found by Vallerand\&Ratelle, (2002); Biddle, Treasure, \& Wang, (2008) Feltz, Irwin, \& Kerr, (2011).

Indeed, intrinsic motivations to knowledge and to leisure fulfillment are more important to consider young people as they their allow to control their behaviors and be motivated for a long time. Intrinsic motivations will give the opportunity to young to be the controller of his behaviour while extrinsic motivations will give this opportunity to someone else. These results go with studies of Ryan \&Deci, (2000); Vallerand, (2007) and FerreCaja, \& Weiss, (2000).

The non-level motivation, young people perceive the links between its actions and results. They control well the reasons for the practice and the results it wants. Young people are in a State of conquest, they experience feelings of harmony (the goals that I set myself and it is necessary to continue to practise a sport) (Roberts, 2001; Guay, Vallerand\& Blanchard, 2000; Roberts, 2001, Kilpatrick, Hebert, \& Bartholomew, 2005). This amotivation can be the cause of several factors such as anxiety which can take very different forms from the simple desire to panic anxiety which often inhibit and paralyses the decision-making among young people. Unlike many studies that show that girls are less sports than boys (Bouhelee, 2005). Fredricks\& al (2005), shows that girls do less sport those boys because they feel less competent and it give less value. According to his model, the difference is not significant between the kind and pattern of practice of a leisure activity. On the other hand, Sarrazin (2009) shows that students were more self-determined for activity when it conveyed a conforming to gender stereotype. Indeed, the intrinsic aspect is better appreciated by women than by men. They attribute less importance to extrinsic component of their role, including the prestige and security to the position (Scadron Arlene \& al., 1982).

\section{Conclusion}

The self-determined motivation is a field of observation and a focused very relevant to the sport. Thanks to this last could detect in this work the way and the reasons for our youth involvement in recreational sports.

However, from statistical results we concluded, first, that the Sfax region youth have a strong intrinsic motivation towards the sport. Participate in activities by intrinsic motivation leads to positive consequences such as greater cognitive flexibility, a better conceptual learning, greater creativity, greater interest, positive emotions and a better considers itself. Also they have an amotivation inversely correlated with (knowledge and fulfilling) intrinsic motivation and extrinsic motivation (identified and introjected) in to recreation. On the other hand, there is no relationship with the extrinsic motivation - external regulation and intrinsic motivation to stimulation. Furthermore they are more oriented towards an intrinsic motivation to stimulation (this is pure pleasure and intense emotions, without research knowledge or performance). End despite possible that methodological and theoretical limitations which may arise. The conclusions of this work nevertheless encourage us to consider it as a starting point in the construction of a more elaborate knowledge of the types of motivations that mobilizing Tunisian youth toward the recreational sports

\section{References}

[1]. Archer, J. \&Haigh, A. M. (1997). Beliefs about aggression among male and female prisoners. AggressiveBehavior, $23,405-415$.

[2]. Atlantis, E., Chow, CM ., Hirby, A., \& Singh. MF. (2004). An effective exercise based intervention for improving mental health and quality of life measures: a randomized controlled trial », Preventive Medicine 39 (2), 424-434.

[3]. Avenell, A., Brown, T.J., McGree, M.A., Campbell, M.K., \& al., (2004). What interventions shouldwe add to weight reducing diets in adult with obesity ?,Journal of Human Nutrition And Dietetics 17 (4), 293-316.

[4]. Biddle, S. J., Treasure, D. C., \& Wang, C. K. (2008). Motivational characteristics. In L. Smith, \& S. J. Biddle (Eds.), Youth physical activity and sedentary behavior.

[5]. Bouhelee, A. (2005). La pratique sportive des jeunes, études INSEE et INSERM, 2003 et 2004.

[6]. Brière, N.M.; Vallerand, R.J.; Blais, M.R. \& Pelletier, L.G. (1995). Développement et validation d'une mesure de motivation intrinsèque, extrinsèque et d'amotivation en contexte sportif : l'Échelle de motivation dans les sports (ÉMS), International Journal of Sport Psychology, 26, 465-489.

[7]. Carey, M. P., \& Lewis, B. P. (1999). Motivational Strategies Can Augment HIV-Risk Reduction Programs. AIDS and Behavior, 3 (4), 269-276.

[8]. Chan Zason L.K \&Jhon Wang C.K, (2008). Motivational profiles of junior college athlètes. A cluster analysis », Journal of Applied Sport Psychology, 20. 137-156.

[9]. Darling, N., Caldwell, L. L., \& Smith, R. (2005). Participation in school-based extracurricular activities and adolescent adjustment. Journal of Leisure Research, 37, 51-76.

[10]. Deci, E. L., \& Ryan, R. M. (2002). Handbook of self-determination research. Rochester, New York: University of Rochester Press.

[11]. Deci, E. L., \& Ryan, R. M. (2008). Facilitating optimal motivation and psychological well-being across life's domains. Canadian Psychology, 49, 14-23.

[12]. Deci, E., E.R. Vallerand, L.G. Pelletier, and R.M. Ryan. (Summer-Fall 1991). "Motivation and Education. The Self-Determination Perspective." Educational Psychologist 26, 3-4: 325-346.

[13]. Deci, E.L. (1975). Intrinsic motivation. New York: Plenum Press.

[14]. Deci, E.L., \& Ryan, R.M. (1985). Intrinsic motivation and self-dermination in human behavior, New-York: Plenum Press. 
[15]. Deci, E.L., \& Ryan, R.M., (2000). The "What" and "Why" of Goal Pursuits: Human Needs and the Self-Determination Theory. Psychological Inquiry 11 (4), 227-268.

[16]. Eurobaromètre "Les citoyens de l'Union européenne et le sport" / novembre 2004.

[17]. Eweing, M.E., \&Seefeldt, V. (1996). Patterns of participation and attrition in American agency-sponsored youth sports» In F.L.Smoll, \&R.E.Smith (Eds.), Children and youth in sport: A biopsychosocial perspective, Madison, WI: Brown \& Benchmark, pp.31-45.

[18]. Feltz, D. L., Irwin, B. C., \& Kerr, N. K. (2011). Match making: An examination of discrepancy inability as a moderator of motivation gains in partneredexercise games. Manuscript submitted for publication.

[19]. FerreCaja, E. \& Weiss, M.R. (2000). Predictors of intrinsinc motivation among adolescent students, In physical éducation. Research quarterly for Exercise and sport 71, 267,279.

[20]. François L. Rousseau; Robert J. Vallerand ; Catherine F. Ratelle ; Geneviéve A. Mageau ; Pierre J. Provencher. Passion and Gambling: On the Validation of the Gambling Passion Scale (GPS). Journal of Gambling Studies, Vol. 18, No. 1, Spring 2002.

[21]. Frederick-Recascino, C. M. (2004). Self-determination theory and participation motivation research in the sport and exercise domain. In E. L. Deci\& R. M. Ryan (Eds.), Handbook of self-determinationresearch (pp. 277-296). Rochester, NY: University of Rochester Press.

[22]. Fredricks, J.A., \&Eccles, J.S. (2005). Family socialisation gender and sport motivation and involvement. Journal of Sport \&ExercisePsychology, 27, 3-31.

[23]. Gill, D.L., Gross, J.B., \& Huddleston, S. (1993). Participation motivation in youth sports, Internationnal Journal Of Sport Psychology, 14, 1-14.

[24]. Gourlan, M. (2007). Diabète de type 2 et activités physiques : Quels profils motivationnels ? Une étude dans le cadre de la théorie de l'autodétermination (dir. D. Trouilloud). Mémoire de Master 2 Mouvement, Performance, Santé. Grenoble : Université Joseph Fourier.

[25]. Guay, F.; Vallerand, R. J.; \& Blanchard, C. (2000). On the assessment of situational intrinsic and extrinsic motivation: the situational motivation scale (SIMS), Motivation and Emotion, 24(3), 175-213.

[26]. Hormuth, S.E. (1986). The sampling of experiences in situ, Jounal of personality, 54, 262-293.

[27]. Iso-Ahola, S.E. (1980). The social psychology of leisure and recreation, Dubuque, Ia: W.C. Brown

[28]. Kaiser, H.F. (1958). The varimax criterion for analytic rotation in Factor Analysis, Psychometrika, 23, 187- 200

[29]. Kelly, J.R. (1982). Leisure. Englelwood Cliffs, n.j.: Prentice Hall. L’Aube.

[30]. Kilpatrick, M., Hebert, E., \& Bartholomew, J. (2005). College students' motivation for physical activity: Differentiating men's and women's motives for sport participation and exercise. Journal of American CollegeHealth, 54, 87-94.

[31]. Lu, Feng. (2008). Leisure Sports. Beijing, People's Sports Publishing House. 2008: 4, 99.

[32]. Miller, Y. D., \& Brown, W. J. (2005). Determinants of active leisure for women with young children- an 'ethic of care' prevails. Leisure Sciences, 27, 405-420.

[33]. Neulinger, J. (1974). The psychology of leisure. Springfield, I11: Charles C. Thomas.

[34]. Pelletier, L.G., Fortier, M.S., Vallerand, R.J. \& Brière, N.M., (2001). Associations between perceived autonomy support, forms of self regulation, and persistence: a prospective study. Motiv Emotion 25, 279-306.

[35]. Richard m. Ryan,juliuskuhl,and edward 1. Deci. 1997. Nature and autonomy: An organizational view of social and neurobiological aspects of self-regulation in behavior and development.Development and Psychopathology, 9 (1997), 701-728.

[36]. Ridder, D., \& Wit, J. (2006). Self-regulation in Health Behavior. Sussex, UK: John Wiley \& Sons.

[37]. Roberts, G. C. (2001). Advances in motivation in sport and exercise. Champaign, IL: Human Kinetics.

[38]. Sabiston, C. M., \& Crocker, P. R. E. (2008). Exploring selfperceptions and social influences as correlates of adolescent leisure-time physical activity. Journal of Sport and Exercise Psychology, 30, 3-22.

[39]. Samdahl, D.M. (1988). A symbolic interactionist model of leisure: theory and Empirical support. Leisure Sciences, 10, 27-39.

[40]. Sarrazin, P., \&AinaChalabaev (2009). Relation entre les stéréotypes sexués associés aux pratiques sportives et la motivation autodéterminée des élèves en éducations physique et sportive, Science et motricité, 66, 61-70.

[41]. Sarrazin, P., Pelletier, L., Deci, E., \& Ryan, R. (2011). Nourrir une motivation autonome et ses conséquences positives dans différents milieux de vie : les apports de la théorie de l'autodétermination. in C. Martin-Krumm, \& C. Tarquinio, Traité de psychologie positive (pp. 273-312). Bruxelles: de Boeck.

[42]. Scadron Arlene \& al. (1982). Attitudes towards women physicans in medical academia. Journal of the American Medical Association, 247:2803-8.

[43]. Schelling, S., Munsch, S., Meyer, A. H., Newark, P., Biedert, E., \&Margraf, J. (2009). Increasing the motivation for phy sical activity in obese patients. International Journal of Eating Disorders, 42 (2), 130-138.

[44]. Simono, R.B. (1991). Anxiety reduction and stress management through physical exercise. In Diamant L. (ed.), Psychology of sport, exercise, and fitness: Social and personal issues (pp.51-66). New York: HemispherePublishing Corporation.

[45]. Smigel, E. (1963). Work and Leisure. New Haven: College and University Press.

[46]. Standage, M., Duda, J.L., \&Ntoumanis, N. (2006). Students' motivational processes and their relationship to teacher ratings in school physical education: A self-determination theory approach. Research Quarterly for Exerciseand Sport, 77, 100-110.

[47]. Szalai, A. (1972). The use time Daily activities of urban and suburban populations in twelve countries. The hague, The Netherlands: Mouton.

[48]. Tinsley, H.E. \&Tinsley, D.J. (1986). A theory of attributes, benefits, and causes of leisure experience. Leisure Sciences, 8, 1-45. UniversitiesPress.

[49]. Vallerand, Pelletier, Green Demers, Blais \& Brière. (1996). Echelle de mesure : motivation vis-à-vis des loisirs (EML) », Loisir et Société, 19,559-585.

[50]. Vallerand, R. J., \&Thill, E. (1993). Introduction à la psychologie de la motivation. Montréal: Editions Etudes Vivantes.

[51]. Vallerand, R. J., Pelletier, L. G., Blais, M. R., Briére, N. M., Sene’ cal, C. B., \&Valliéres, E. F. (1992). The academic motivation scale: A measure of intrinsic, extrinsic, and amotivation in education. Educational and PsychologicalMeasurement, 52, $1003-1017$.

[52]. Vallerand, R.J., \&Ratelle, C.F., (2002). Intrinsic and extrinsic motivation: a hierarchical model. In: Deci, E.L., Ryan, R.M. (Eds.), Handbook of self-determination research. University of Rochester Press, Rochester, NY, pp. 37-63.

[53]. Vallerand, R.J., (2007). Ahierarchical model of intrinsic and extrinsic motivation for sport and physical activity. In: Hagger, M.S., \&Chatzisarantis, N.L.D. (Eds.), Self-determination theory in exercise and sport. Human Kinetics, Champaign, IL, pp. 255-279.

[54]. Wankel, L.M., \&Kreisel, S.J.P. (1985). Factors underlying enjoyment of youth sports: Sport and age group comparisons,Journal of Sport Psychology, 7, pp.51-64. 